УДК 902/903.4/904

https://doi.org/10.24852/2587-6112.2021.2.29.46

\title{
КУЛЬТУРНО-ХРОНОЛОГИЧЕСКИЕ КОМПЛЕКСЫ КУРМАНАКОВСКОЙ IV СТОЯНКИ В НИЖНЕМ ТЕЧЕНИИ РЕКИ МЕША
}

\author{
(C) 2021 г.А.В. Лыганов
}

В статье рассматриваются керамические, кремневые и металлические изделия полученные в результате исследования жилищной впадины на Курманаковской IV стоянке. По керамике удалось выявить четыре культурно-хронологических горизонта на памятнике. Первый горизонт представлен керамикой и кремневыми изделиями средневолжского варианта волосовской КИО. Второй хронологический комплекс представлен гибридной керамикой покровского этапа срубной КИО и финала волосовской культуры. К третьему этапу относятся самые многочисленные находки керамики и кремневых изделий раннего (атабаевского) этапа маклашеевской культуры и культуры текстильной керамики времени ее становления в Приказанском Поволжье. К этому периоду относится сооружение землянки на территории стоянки. Керамика маклашеевской культуры позднего (маклашеевского) этапа и гибридная керамика с признаками гончарных традиций носителей маклашеевской культуры и культуры текстильной керамики финала позднего бронзового века выявлена в верхних горизонтах заполнения жилища. К финалу позднего бронзового века относится и $\mathrm{AMS}{ }^{14} \mathrm{C}$ дата, полученная из обугленного бревна в переходе между землянками - 2 б (96\%) 1274-1055 кал.л. до н.э. (UOC-13395, INTCAL20).

Ключевые слова: археология, р. Меша, энеолит, волосовская культура, поздний бронзовый век, керамика, изготовленная в «срубных» традициях, поздняковская культура, атабаевский этап маклашеевской культуры, культура текстильной керамики, маклашеевская культура, AMS ${ }^{14} \mathrm{C}$ даты.

\section{CULTURAL AND CHRONOLOGICAL COMPLEXES OF KURMANAKOVO IV SITE IN THE LOWER REACHES OF THE MESHA RIVER}

\section{A.V. Lyganov}

The paper addresses the ceramic, flint and metal items obtained as a result of the study of a residential hollow at the Kurmanakovo IV site. The ceramics made it possible to identify four cultural and chronological horizons at the site. The first horizon is represented by ceramics and flint items of the Middle Volga variant of the Volosovo Cultural and Historical Area. The second chronological complex is represented by hybrid ceramics of the Pokrovka stage of the Srubnaia Cultural and Historical Area and the final period of the Volosovo culture. The third stage includes the most numerous discovered ceramic and flint items of the early (Atabaevo) stage of the Maklasheevka culture and the culture of textile ceramics of the period of its formation in the Kazan Volga Region. The construction of a dugout in the territory of the site is related to this period. Ceramics of the Maklasheevka culture of the late (Maklasheevka) stage and hybrid ceramics with signs of pottery traditions of the carriers of the Maklasheevka culture and the culture of textile ceramics of the final stage of the Late Bronze Age were revealed in the upper horizons of a dwelling's filling material. The AMS ${ }^{14} \mathrm{C}$ date obtained using a charred log in the passage between dugouts also belongs to the final stage of the Late Bronze Age -2 $\sigma(96 \%) 1274-1055$ cal. years BC. (UOC-13395, INTCAL20).

Keywords: archaeology, Mesha river, Eneolithic, Volosovo culture, Late Bronze Age, ceramics made according to "Srubna" traditions, Pozdnyakovo culture, Atabaevo stage of the Maklasheevka culture, the culture of textile ceramics, Maklasheevka culture, AMS ${ }^{14} \mathrm{C}$ dates.

Курманаковская IV стоянка расположена в нижнем течении р. Меши правого притока р. Камы в 1 км севернее деревни Курманаково Лаишевского района РТ. Стоянка находится на останце дюнного возвышения в пойме правобережья реки. Разрушенная часть дюны вплотную примыкает с юга к надпойменной террасе высотой около 6-7 метров, сложенной суглинками. Поверхность стоянки значитель-

но разрушена береговой абразией Куйбышевского водохранилища, значительно подтопившего пойму р. Меши, а также выемкой песка для создания спуска к реке и для производственных нужд. Вплотную к территории стоянки примыкает заболоченная древняя протока (рис. 1, 2).

В 2014 и 2017 гг. на разрушающейся части стоянки проведены раскопки на площади 


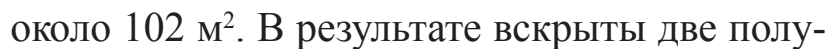
разрушенные постройки глубиной 70-100 см от древней поверхности. Предварительные итоги работ опубликованы (Лыганов, 2019а, 2019б). В данной статье более подробно рассматриваются вопросы хронологии существования комплексов стоянки с опорой на керамический, кремневый и металлический инвентарь, а также результат радиоуглеродного датирования обугленного бревна из перехода между жилищами.

Курманаковская IV стоянка входит в достаточно хорошо археологически изученный микрорайон нижнего течения р. Меши (рис. 1Б). Здесь известны как поселения, ставшие реперными, так и могильники и случайные находки атабаевского времени маклашеевской культуры (Атабаевская I стоянка, Рождественский I могильник, Ташкирменские и Епанчинские находки). При этом в этом регионе практически на каждом из памятников известны и находки текстильной керамики и маклашеевского этапа маклашеевской культуры. В ближайшей округе Курманаковской IV стоянки разведочными работами исследованы Курманаковская VI стоянка и Дятловская стоянка с материалом культуры текстильной керамики. Таким образом, широкое освоение этой территории произошло во второй половине II тыс. до н. э. Не является исключением и Курманаковская IV стоянка, жилище и основной комплекс предметов которой относится к этому времени.

Стратиграфия раскопов Курманаковской IV стоянки вне жилищной западины следующая (рис. 3). В верхней части идет слой дерна мощностью до 5-7 см. Далее идет слой светло-желто-серого слоистого песка (аллювиальных отложений) мощностью от 12-15 см вне территории жилищной западины и до 30 см в самой низкой точке западины. Находок в нем не выявлено. По происхождению этот слой, вероятно, образовался в процессе высоких половодий р. Меши и перекрыл культурные напластования первобытной стоянки. Судя по находкам гончарной сероглиняной керамики XVIII-XIX вв. в верхней части нижележащего культурного слоя стоянки, эти половодья происходили в Новое время. Аналогичные наблюдения были сделаны на Пестречинской IV стоянке, расположенной в среднем течении р. Меши (Галимова, Лыганов, 2019, с. 41-42).

Далее идет слой серой гумусированной супеси (погребенной почвы), который является культурным слоем стоянки. Здесь выявлены находки от эпохи энеолита до финала позднего бронзового века, а в верхней части - керамика Нового времени (табл. 1). Мощность этого слоя также значительно разнится на разных участках раскопа. Вне территории жилищной западины мощность слоя достигает 45 см, в самой западине над землянкой мощность этого слоя 20-25 см. Здесь выявлено большое количество мелких, окатанных фрагментов керамики и отходов кремневого производства, с трудом поддающихся культурной интерпретации. Над жилищной западиной этот слой сформировался уже после покидания этой территории людьми в финале бронзы, когда происходило постепенное заполнение оплывающим грунтом ямы котлована. Отсюда и такая смесь находок различного времени.

Помимо этого, на участках, не затронутых котлованом жилища, ниже слоя серой гумусированной супеси в профилях прослежен слой светло-серой гумусированной супеси мощностью 5-20 см. Границы с вышележащим слоем очень нечеткие (рис. 3: 2). Здесь сосредоточены фрагменты керамики эпохи энеолита и керамики, изготовленной в т. н. «срубных» традициях. Судя по стратиграфическим наблюдениям, именно в этом слое в древности был вырыт котлован жилища.

Заполнение жилища-землянки состоит из нескольких прослоек. В верхней части заполнения землянки зафиксирована прослойка из серой супеси с включением пятен желтого песка. Граница ее с выше- и нижележащими слоями очень нечеткая и фиксируется только в профилях и бровках раскопов. Мощность прослойки неодинакова на разных участках. Ближе к центру землянки ее мощность составляет 5-8 см, возле краев землянки, но не у самой стенки, мощность прослойки достигает 25 см. Прослойка насыщена большим количеством фрагментов колотого кварцита разных размеров. Светло-серая супесь с включением пятен желтого песка образовалась, вероятно, после того, как сгорела первоначальная конструкция землянки, а котлован, возможно, после отсыпки песком использовался уже вторично носителями маклашеевской культуры. На это указывают находки финала бронзового века преимущественно в этом слое и на этой глубине, а также большого количества кварцитовых обломков (рис. 4: 4). Использование кварцитовых орудий, наряду с кремнем, характерно именно для маклашеевской культуры (Галимова, 2014).

Основным заполнением котлована землянки является слой темно-серой супеси с вклю- 

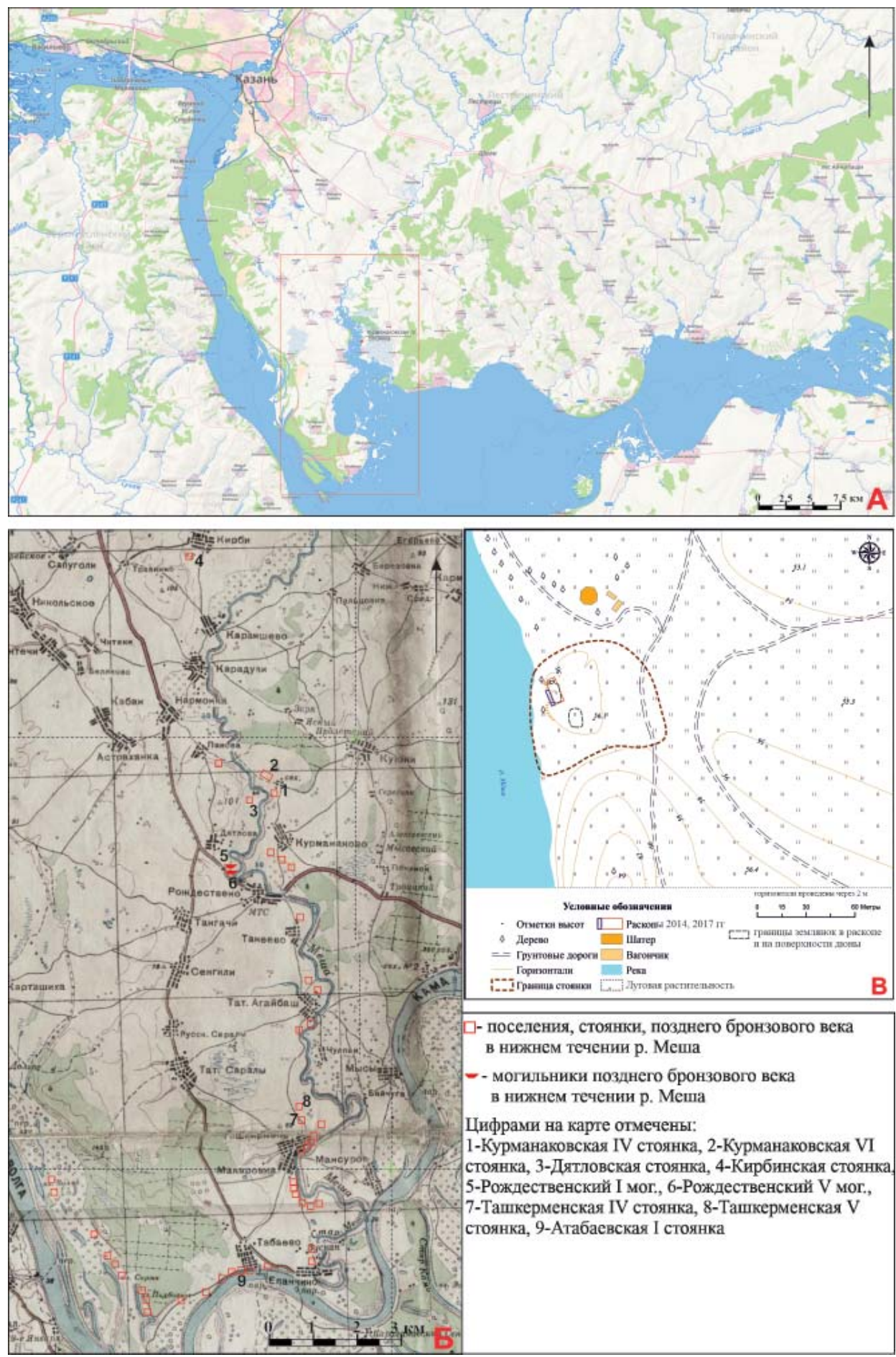

Рис. 1. A - Нижнее течение р. Меша и расположение Курманаковской IV стонки; Б - Нижнее течение р. Меша до затопления Куйбышевским водохранилищем и памятники эпохи бронзы (топооснова - Карта РККА 19361947 гг. с масштабом 1:2.5M - 1:100К. Источник: http://retromap.ru/); В - План Курманаковской IV стоянки с нанесенными раскопами 2014 и 2017 гг.

Fig. 1. A - Lower course of the Mesha river and location of Kurmanakovo IV site; $\mathrm{L}$ - Lower course of the Mesha river before flooding by the Kuibyshev reservoir and sites of the Bronze Age (topographic base - Map of the Red Army 1936-1947 at a scale of 1: 2.5M - 1: 100K. Source: http://retromap.ru/); B - Plan of Kurmanakovo IV site the marked excavations of 2014 and 2017.

чением большого количества углей. Наибольшая мощность этого слоя до 1 м прослежена у выявленных краев землянки. Наименьшая мощность слоя в 30 см в центральной части котлована. Этот слой выявлен также в заполнении материковых ям дна землянки. В нижней части заполнения землянки и в ямах не зафиксирована самая ранняя керамика эпохи энеолита, а также маклашеевская керамика финала бронзового века (табл. 1).

Два жилища были зафиксированы на глубине -100 см от 0 в виде одного объемно- 


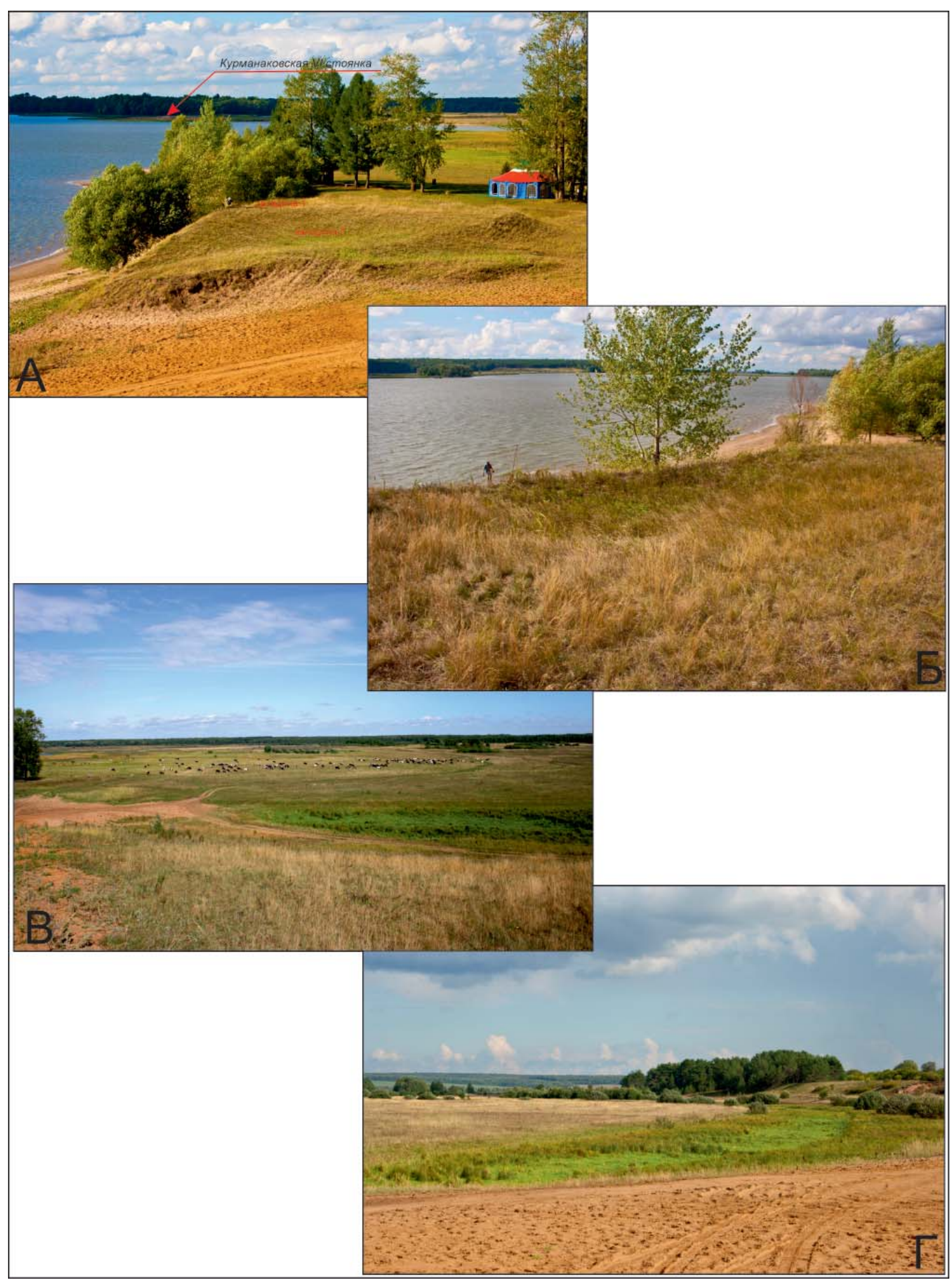

Рис. 2. А - Фото дюнного останца, на котором расположена Курманаковская IV стоянка. Вид с юга; Б - Фото разрушенной жилищной западины. Вид с юго-востока; В - Вид на пойму р. Меша с территории Курманаковской

IV стоянки; Г - Заболоченная протока р. Меша, проходящая вдоль Курманаковской IV стоянки.

Fig. 2. A - Photo of a dune outlier where Kurmanakovo IV site is located. View from the south; Б - Photo of a destroyed residual hollow. View from the south-east; B - View of the floodplain of the Mesha river from the territory of Kurmanakovo IV site; $\Gamma$-Swampy course of the Mesha river passing along Kurmanakovo IV site.

го пятна размерами 6,5×16 м, занимающего фактически всю поверхность двух раскопов (рис. 5). На глубине 140-180 см сооружения разделились - между ними был зафиксирован переход, в котором лежала обугленная конструкция из трех бревен: два бревна внизу и сверху еще одно бревно. Сооружение 1 на этой глубине стало значительно меньше - его размеры составили $11 \times 8$ м. Единственной полностью сохранившейся восточной стенкой длиной 11 м землянка ориентирована по направлению север - юг с незначительными отклонениями на северо-восток - юго-запад. Западная часть землянки, а также участки 
Таблийа 1.

Распределение керамики по глубинам на Курманаковской IV стоянке

Table 1.

Distribution of ceramics by depth at Kurmanakovo IV site

\begin{tabular}{|c|c|c|c|c|c|c|c|c|c|c|}
\hline Пласт & $\begin{array}{l}\text { Энео- } \\
\text { лит }\end{array}$ & $\begin{array}{c}\text { В } \\
\text { «срубных } \\
\text { тради- } \\
\text { циях» } \\
\end{array}$ & KTK & $\begin{array}{l}\text { Атабаев- } \\
\text { ский } \\
\text { этап }\end{array}$ & $\begin{array}{c}\text { Макла- } \\
\text { шеев- } \\
\text { ский } \\
\text { этап } \\
\end{array}$ & \begin{tabular}{|c|} 
Поздня- \\
ков- \\
ская
\end{tabular} & $\begin{array}{c}\text { Нового } \\
\text { времени }\end{array}$ & $\begin{array}{c}\text { Не- } \\
\text { опреде- } \\
\text { ленно }\end{array}$ & Всего & $\begin{array}{c}\text { Кремень } \\
\text { и } \\
\text { кварцит } \\
\text { отходы } \\
\end{array}$ \\
\hline 1 пласт аллювий & & & & & & & & & & \\
\hline $\begin{array}{l}2 \text { пласт } \\
\text { культурный } \\
\text { слой }\end{array}$ & & 34 & 4 & 11 & & 2 & & 130 & 181 & 57 \\
\hline $\begin{array}{l}3 \text { пласт } \\
\text { культурный } \\
\text { слой }\end{array}$ & 21 & 60 & 53 & 28 & 8 & 3 & 7 & 228 & 404 & 70 \\
\hline $\begin{array}{l}\text { плласт } \\
\text { заполнение } \\
\text { землянки }\end{array}$ & & 19 & 63 & 92 & 7 & 3 & & 239 & 423 & 114 \\
\hline $\begin{array}{l}5 \text { пласт } \\
\text { заполнение } \\
\text { землянки } \\
\end{array}$ & 5 & 31 & 58 & 30 & 55 & 8 & & 289 & 483 & 71 \\
\hline $\begin{array}{l}6 \text { пласт } \\
\text { заполнение } \\
\text { землянки }\end{array}$ & 1 & 8 & 20 & 28 & 12 & 3 & & 242 & 315 & 52 \\
\hline $\begin{array}{l}7 \text { пласт } \\
\text { заполнение } \\
\text { землянки }\end{array}$ & & 2 & 5 & 16 & & 5 & & 130 & 158 & 29 \\
\hline $\begin{array}{l}\text { В } \\
\text { хозяйственных } \\
\text { и столбовых } \\
\text { ямах в полу } \\
\text { землянки }\end{array}$ & & 1 & 11 & 46 & & & & 44 & 90 & 21 \\
\hline $\begin{array}{l}\text { Всего / \% от } \\
\text { определенной } \\
\text { керамики }\end{array}$ & $\begin{array}{c}27 / \\
3,8 \%\end{array}$ & $155 / 20 \%$ & $\begin{array}{l}214 / \\
28 \%\end{array}$ & $251 / 33 \%$ & $82 / 11 \%$ & $24 / 3,3 \%$ & $7 / 0,9 \%$ & 1302 & 2054 & 414 \\
\hline
\end{tabular}

прилегающих к ней северной и южной стенок полностью разрушены водохранилищем, так что нельзя сказать о ее действительной площади. Глубина котлована уровня выявления у южной стенки достигает 1 м. Дно плоское с уклоном с юга на север 25-30 см.

Сооружение № 2 размерами $2 \times 5$ м соединено с сооружением № 1 тамбуром-переходом длиной около 2 м и глубиной около $20 \mathrm{~cm}$ от уровня фиксации. В раскопе зафиксирована только часть его южной и западной стенки. Судя по близости к обрыву, сооружение № 2 также значительно разрушено Куйбышевским водохранилищем. Глубина его от уровня выявления около $70 \mathrm{~cm}$.

Вдоль краев землянок при выборке на всех пластах в большом количестве фиксировались углистые полосы от сгоревших бревен. Столбовые ямы были зафиксированы вдоль южного края и восточного края сооружения № 1. Вдоль восточного края столбовые ямы идут в два ряда, расстояние между которыми около 2 м. Таким образом, можно говорить о каркасно-столбовой конструкции жилища № 1. Также вдоль южного края котлована жилища № 1 были выявлены не менее 10 хозяйственных ям различного размера (рис. 5). В центральной части сооружения № 1 был зафиксирован маломощный прокал от наземного очага.

Вероятно, условно выделенные землянки (сооружения): № 1 и № 2 являются разделенными помещениями в одном жилище. Такой вывод получен из того, что эти два разделенных помещения находятся в одном видимом на поверхности котловане, зафиксированы первоначально в виде единого пятна, перегородка между жилищами № 1 и № 2 невысока - ниже южной и восточной стенок жилища № 1 и составляет 40-50 см от уровня материка. Наиболее близки курманаковским жилищам по конфигурации постройки атабаевского этапа маклашеевской культуры на Ошутьяльском III поселении и жилища на Гулькином бугре (Соловьев, 2000, рис. 64; Збруева, 1960). 


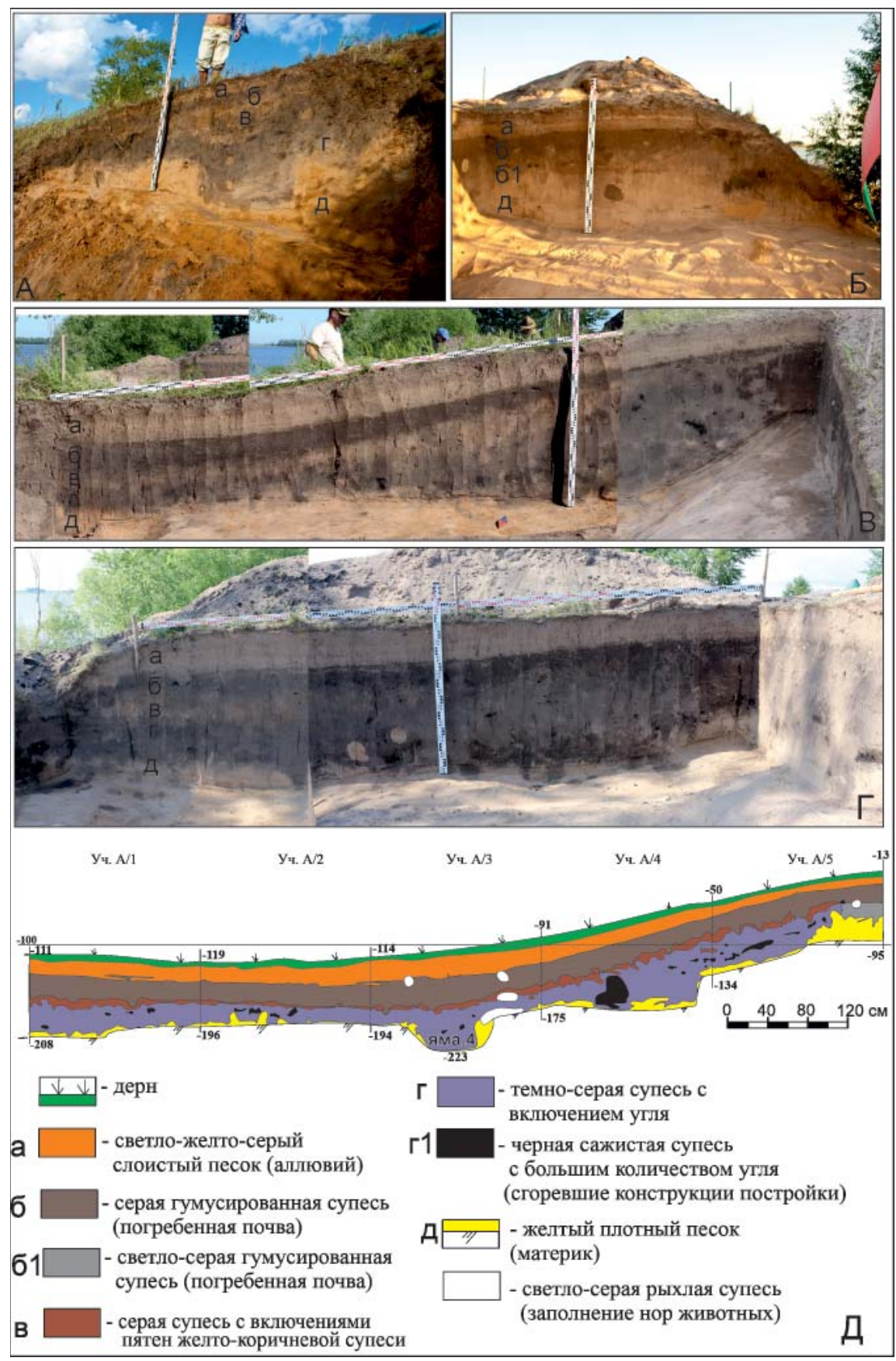

Рис. 3. Профили раскопов Курманаковской IV стоянки. А - Зачистка берегового обнажения. Вид с юго-запада; Б - Культурный слой вне жилищной западины на уч. а/5. Вид с севера; В - Профиль бровки, проходящей через землянку 1 на уч. 3Б-3Г. Вид с юга; Г-Профиль северной стенки раскопа, проходящей через землянку 2 на уч. $3^{1}$ Б- $3^{1} \Gamma$. Вид с юга. Д - Разрез землянки 1 на уч. А1-А5.

Fig. 3. Profile of excavations at Kurmanakovo IV site. A - Cleaning of a coastal outcrop. View from the south-west; B - Cultural layer outside the residential hollow in section a/5. View from the north; B - Profile of an edge passing through dugout 1 at section $3 Б-3 \Gamma$. View from the south; $\Gamma$ - Profile of the northern wall of the excavation, passing through dugout 2 in section $3^{1} \mathrm{~L}^{-} 3^{1} \Gamma$. View from the south. Д- Section of the dugout 1 in section A1-A5.

Керамический материал. Несмотря на четко выраженные напластования в стенках и бровках раскопов, керамика в культурном слое стоянки и в заполнении землянки залегает в перемешанном виде (табл. 1). Всего найдено свыше 2 тыс. фрагментов керамики, относящихся к различным культурно-хронологическим горизонтам.

Первый культурно-хронологический горизонт (конец III тыс. до н. э.) соответствует финалу энеолита и представлен на стоянке 27 фрагментами пористой легкой керамики с гребенчатым орнаментом (4\% от всей определенной керамики) (рис. 6). К этому же горизонту можно отнести днище плоскодонного сосуда относительно толстостенного с орнаментацией гребенчатым штампом (рис. 6: 9). Энеолитическая керамика залегала преимущественно на уч. А/5 в основании культурного слоя вне территории жилищной западины. 


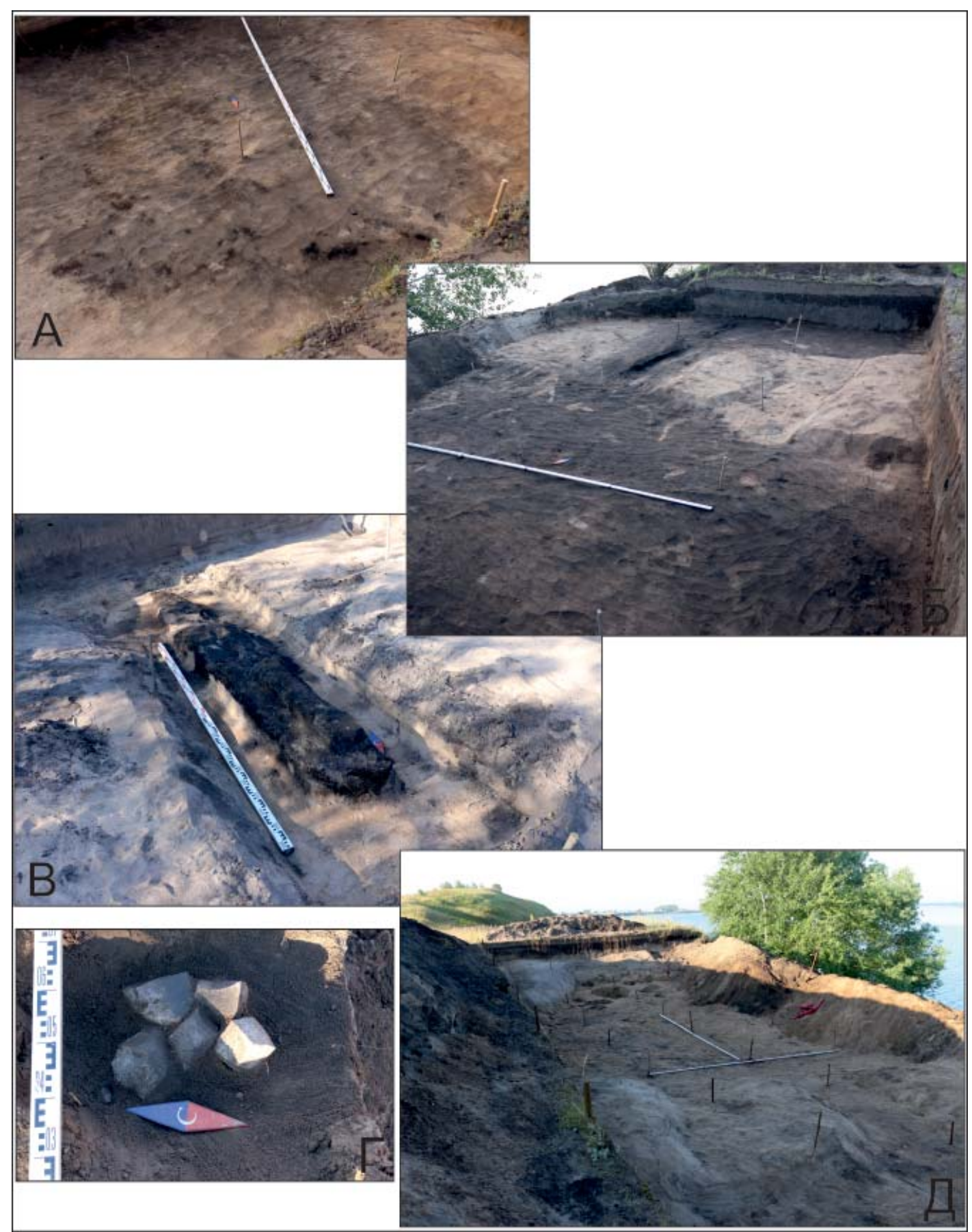

Рис. 4. А- углистые полосы вдоль стенки землянки 1; Б - Контуры землянки 1 и 2 соединённые между собой переходом; В - конструкция из бревен в переходе между землянками; Г-скопление колотого кварцита в верхней части заполнения землянки 1 ; Д - землянки 1 и 2 после выборки.

Fig. 4. A - carbonaceous strips along the wall of the dugout $1 ; Б$ - Contours of dugouts 1 and 2 connected by a transition; B - construction of logs in the transition between dugouts; $\Gamma$ - accumulation of crushed quartzite in the upper part of the filling of dugout 1 ; Д-dugouts 1 and 2 after sampling.

Этот керамический комплекс находит свои аналогии в древностях средневолжского варианта волосовской культурно-исторической общности, в частности на близко расположенных к Курманаковской IV стоянке поселенческих памятниках Приказанского Поволжья: Сумская, Масловская IV, Матюшинские IV, V стоянки (Археологическая..., 1981, табл. III). Данная керамика схожа по орнаментации из рядов гребенки с широко поставленными зубцами, на некоторых фрагментах находятся валики (Археологическая..., 1981, табл. III). По находке фрагмента керамики с валиком на Курманаковской IV стоянке (рис. 6: 2) весь этот комплекс можно отнести к финалу волосовской культуры Волго-Камья (Соловьев, 2000, c. 36-39).

Второй горизонт (первая половина II тыс. до н. э.) соответствует времени проникновения в Предкамье культурного влияния сруб- 


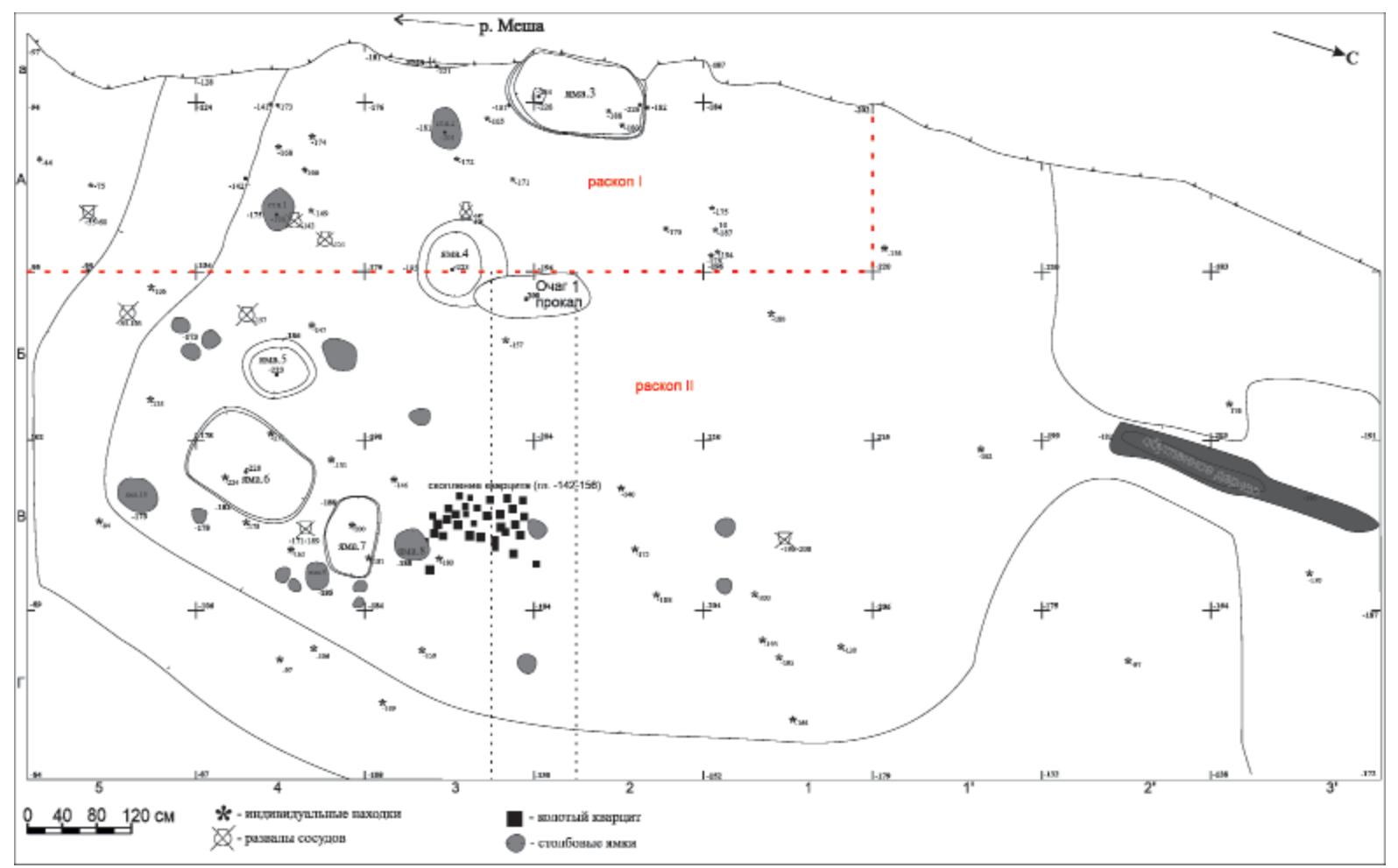

Рис. 5. План раскопов на Курманаковской IV стоянке на уровне материка.

Fig. 5. Plan of excavations at Kurmanakovo IV site at continent level.

ной КИО, что отразилось в появлении на территории стоянки носителей керамики, изготовленной в т. н. «срубных» традициях (155 фрагментов, или 20\% от всей определенной керамики) (рис. 7: 1-13). Со срубной керамикой ее сближает баночная форма, небрежно заглаженная поверхность, иногда с расчесами, неровные вдавления овальной и подтреугольной формы. Подобная керамика широ- ко отмечена в наиболее ранних покровских памятниках Среднего Поволжья и характерна в целом для всего времени существования срубной КИО (Кузьмина, 2017, рис. 62-65). Однако такая керамика, имеющая схожесть со срубной, впервые отмечена в Предкамье. Существуют и значимые отличия в посуде с Курманаковской IV стоянки. Это значительная примесь в тесте сосуда песка, органики и

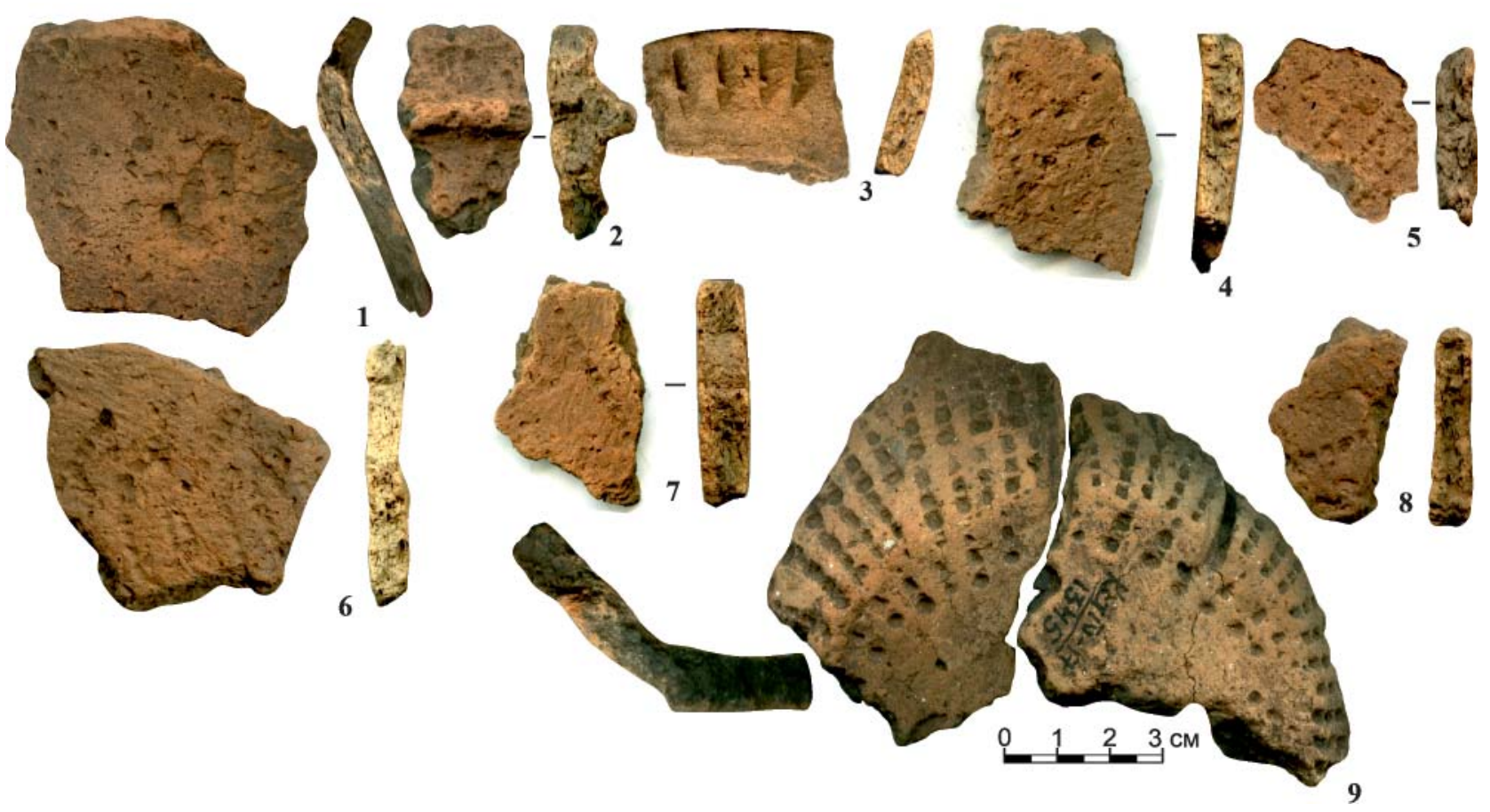

Рис. 6. Керамика волосовской культуры с территории стоянки.

Fig. 6. Ceramics of the Volosovo culture from the site. 


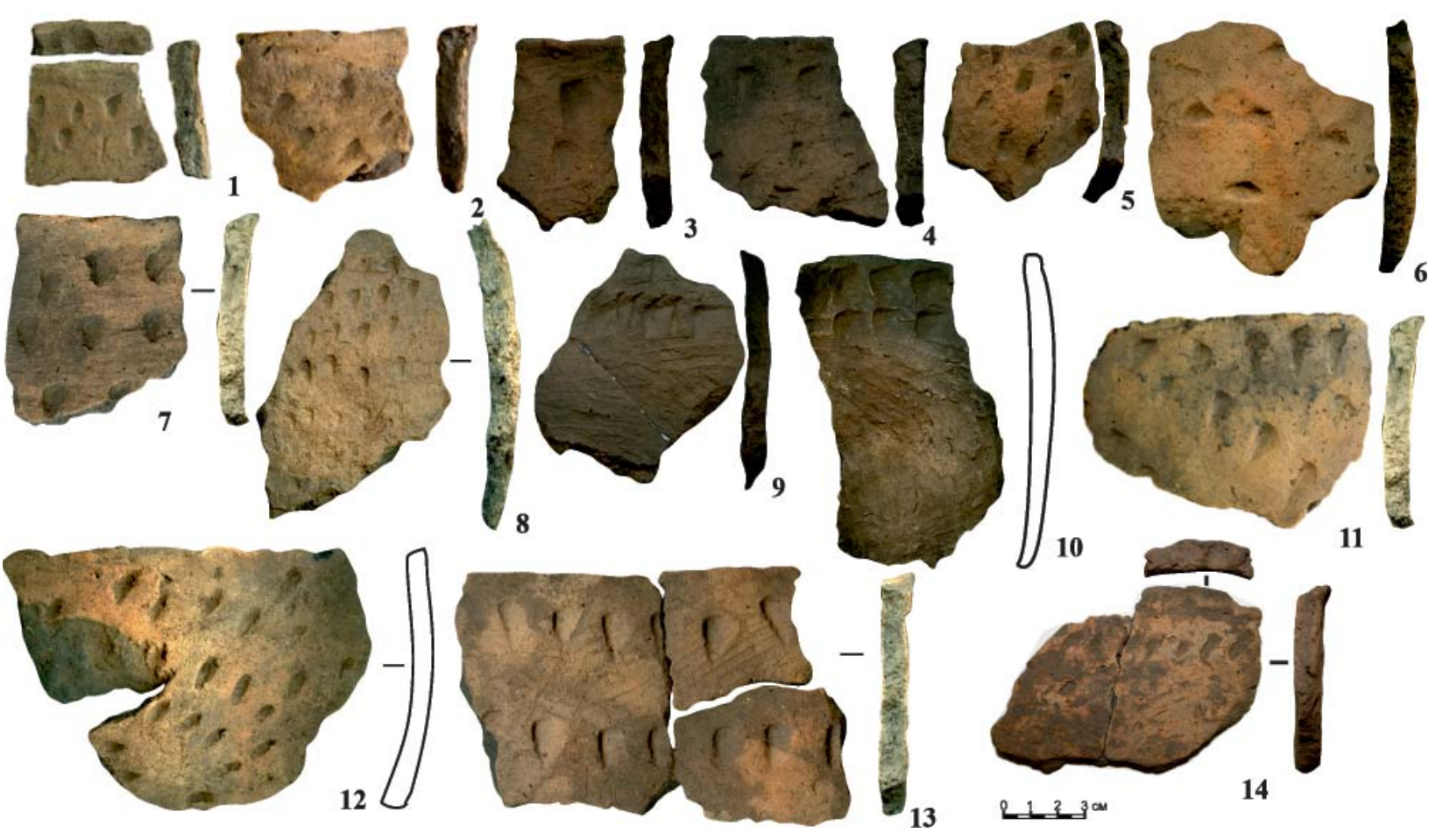

Рис. 7. Керамика, изготовленная в «срубных» традициях.

Fig. 7. Ceramics made according to "Srubnaya" traditions.

известковой крошки, плохой костровой обжиг и отсутствие в орнаменте гребенчатых оттисков. Кроме этого, на подавляющее большинство срезов венчиков с Курманаковской IV стоянки нанесены овальные и округлые вдавления, придающие венчику «гофрированный» вид. Большинство венчиков имеет выступ наружу. Такая орнаментация среза с выступом наружу характерна для средневолжского варианта волосовской КИО, гаринской культуры Прикамья (Никитин В.В., 2017, рис. 156-164; Шипилов, 2021, рис. 21-23). Известен венчик с подобным оформлением среза и с Пестречинской IV стоянки (рис. 7: 14). Все

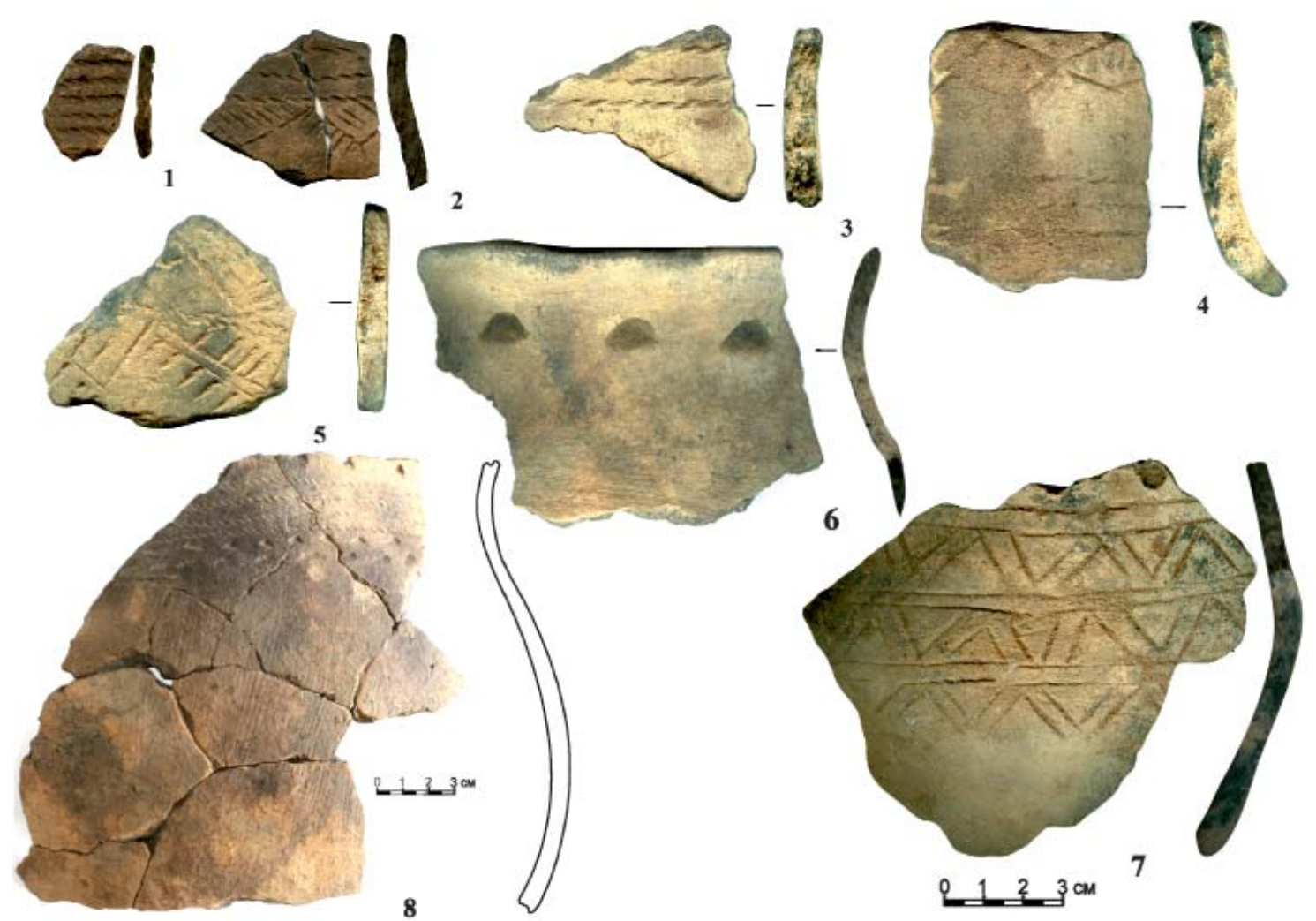

Рис. 8. Керамика близкая по орнаментальным традициям поздняковской культуре.

Fig. 8. Ceramics similar to the Pozdnyakovo culture in terms of ornamental traditions. 
это заставляет предполагать симбиоз культурных традиций покровского этапа (культуры) срубной КИО и поздних волосовских памятников в Приказанском Поволжье.

Судя по некоторым наблюдениям на территории стоянки, эти керамические комплексы по времени предшествуют появлению здесь атабаевской и текстильной керамики и сооружению землянки. Так, развалы керамики в «срубных» традициях зафиксированы на уч. $\mathrm{A} / 5$ и Г/5 в основании культурного слоя вне территории жилищного котлована.

Помимо керамики, изготовленной в «срубной» традиции, на раскопе зафиксирована немногочисленная поздняковская керамика с характерными рядами шнуровых отпечатков по тулову или вдавлениями (24 фрагмента или 3,3\% от всей определенной керамики) (рис. 8). Аналогичная керамика известна в том числе в балымско-карташихинских древностях Казанского Поволжья и поздняковских поселениях на Верхней Волге (Калинин, Халиков, 1954, рис. 4; Халиков, 1980, табл. 26: 25; Бадер, Попова, 1987, рис. 70; Азаров, 2013, рис. 7). Стоит отметить восстановленную стенку сосуда с Курманаковской IV стоянки, где помимо четырех рядов отдельных линий, сделанных оттисками шнура, расположены два ряда небольших подтреугольных вдав- лений, в большей степени характерных для андроноидных культур Приуралья (рис. 8: 8). Керамика, украшенная шнуром, встречается в погребениях луговской культуры (XVII-XV вв. до н. э.). Исследователи связывают появление посуды, украшенной шнуром, с влиянием поздняковской культуры на луговскую культуру (Чижевский и др., 2011). Таким образом, керамика, украшенная шнуром, моложе керамики, изготовленной в «срубных» традициях.

Поселения, на которых совместно залегают т. н. «срубоидная» и поздняковская керамика, выявлены западнее - в Марийском Поволжье и в бассейне р. Оки. Речь идет, прежде всего, о широко раскопанных Шокшинском и Акозинском поселениях (Ставицкий, 2008, с. 188-189, рис. 256-258, 268-269, 272; Халиков, 1960, с. 167-173, табл. LXVII, LXVIII). Керамика, изготовленная в срубных традициях, как и поздняковская, встречается на всех пластах раскопов на Курманаковской IV стоянке (табл. 1). Временные рамки существования подобных типов керамики достаточно спорны ввиду слабой разработанности хронологии и периодизации поздняковской культуры и единичных памятников со «срубоидной» керамикой. Нижней датой весьма условно можно принять XVIII в. до н. э. как время проникно-
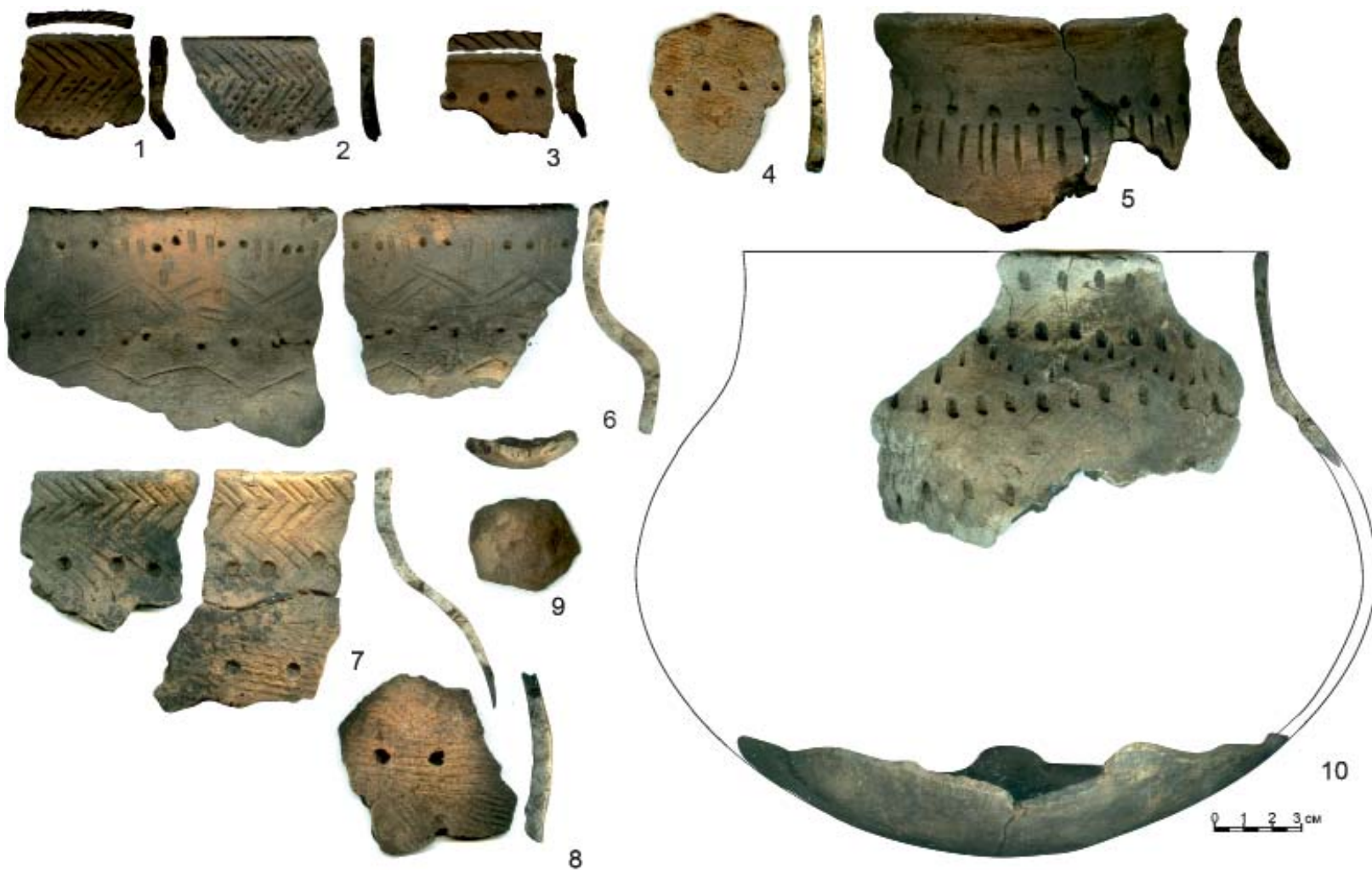

Рис. 9. Керамика культуры текстильной керамики, залегающая на полу землянки 1 и в заполнении хозяйственных ям.

Fig. 9. Ceramics of the textile ceramics culture lying on the floor of dugout 1 and in the filling material of utility pits. 


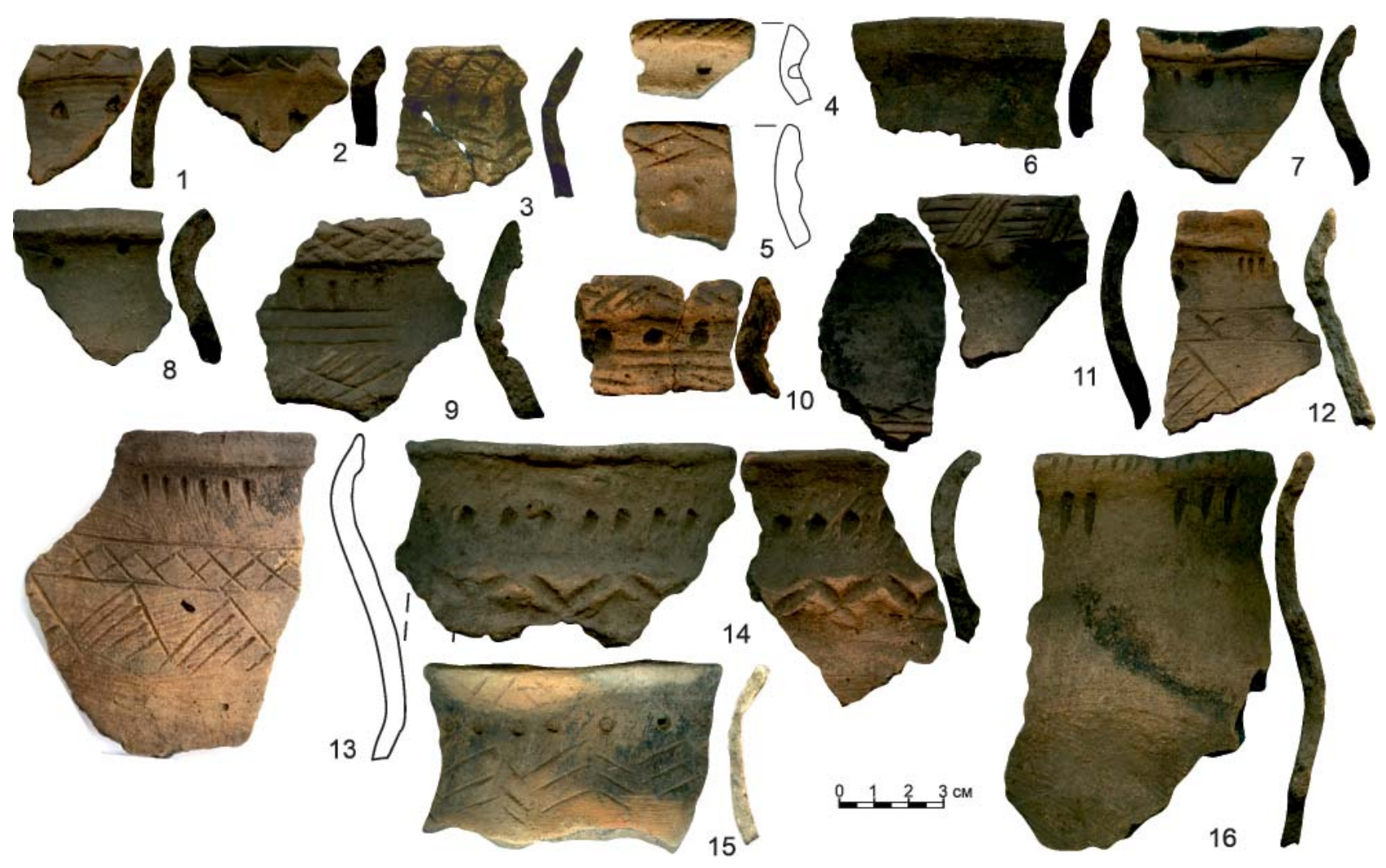

Рис. 10. Керамика атабаевского этапа маклашеевской культуры, залегающая в нижней части заполнения землянок 1-2

Fig. 10. Ceramics of the Atabaevo stage of the Maklasheevka culture lying in the lower part of the filling material of dugouts 1-2

вения влияния в Предкамье срубной культуры на ее развитом этапе. Верхней датой можно принять XV/XIV в. до н. э., когда в Предкамье появились носители атабаевских и текстильных традиций, а на Курманаковской IV стоянке была сооружена землянка. Таким образом, второй хронологический горизонт Курманаковской IV стоянки может быть определен достаточно широко в рамках всей первой половины II тыс. до н. э. Вероятно, более ранней является керамика, изготовленная в «срубных» традициях, на которой фиксируются черты срубной КИО и некоторые позднеэнеолитические признаки. Более поздней выглядит керамика с отпечатками шнура, на которой можно отметить ряд андроноидных мотивов в орнаментации (рис. 8: 8).

К третьему горизонту (XIV-XIII вв. до н. э.) на территории стоянки относится постройка жилища-землянки носителями культурных традиций атабаевского этапа маклашеевской культуры и носителями культуры текстильной керамики (далее - КТК) (рис. 9-11). Сосуществование этих культурных традиций было прослежено на материалах ряда поселений Марийского Поволжья (Патрушев, 2017). При этом в Приказанском Поволжье не прослеживается гибридных форм керамики этого периода. Керамика этих двух культур самая многочисленная на раскопах - свыше 60\% от всей определенной керамики. Керамика атабаевского этапа составляет 251 фрагмент, или $33 \%$ от всей определенной керамики, а керамика КТК - 214 фрагментов, или 28\% от всей определенной керамики. Эти керамические комплексы встречаются на всех пластах раскопов и во всех материковых хозяйственных и столбовых ямах (табл. 1). На дне землянки зафиксированы развалы сосудов КТК (рис. 9: 6, 7, 10). Судя по форме и орнаментации, эти развалы относятся ко времени становления КТК в Приказанском Поволжье среди орнаментации присутствуют элементы, характерные для поздняковской культуры, но при этом уже появляются текстильные отпечатки (рис. 9: 6).

Атабаевская керамика разнообразна и, судя по орнаментации и по оформлению валика/ воротничка на венчике, может быть отнесена к нескольким этапам.

На более ранней керамике присутствуют орнаментальные мотивы, характерные для андроноидных культур Прикамья (заштрихованные треугольники, иногда с бахромой, ряды прочерченных горизонтальных линий и др.) (рис. 10: 7, 9, 12, 13; 11: 6). Валик 


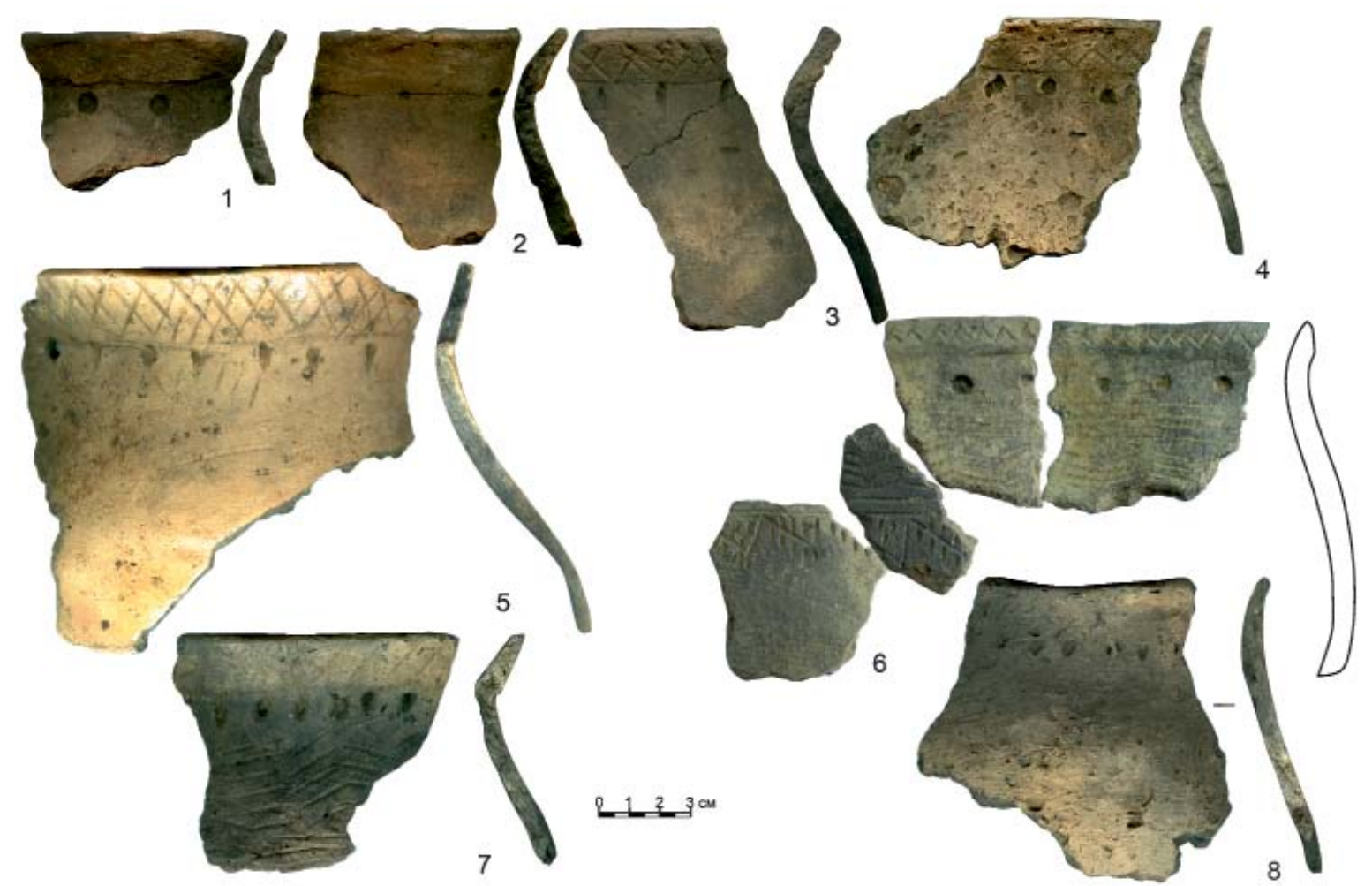

Рис. 11. Керамика атабаевского этапа маклашеевской культуры, залегающая в нижней части заполнения землянок 1-2.

Fig. 11. Ceramics of the Atabaevo stage of the Maklasheevka culture lying in the lower part of the filling material of dugouts 1-2.

подтреугольный приостренный или округлый. Некоторые фрагменты имеют орнамент, характерный для южных и западных культур этого времени. Так, один из фрагментов из хозяйственной ямы в сооружении 1 (рис. 8: 7) находит аналогии в сосуде из могильника Дикариха, который относится к КТК, но при этом наиболее ранний и имеет также аналогии в поздняковской культуре (Никитин А.Л., 1973, рис. 8: 34, 37, 43). В придонной части жилища выявлен развал сосуда, на котором при атабаевском орнаменте, в виде вдавлений по верхней части венчика, присутствует нарезной валик с «усами», расположенный по плечику (рис. 10: 14). Такие валики с «усами» характерны для керамики ивановской (хвалынской) культуры степного Поволжья (Колев, 2008, табл. 3; Малов, 2013, рис. 4). Также нестандартен ряд атабаевской керамики с выпуклинами-жемчужинами под уплощенным орнаментированным валиком (рис. 10: 5, 11). Эта орнаментация характерна для древностей аким-сергеевского типа. Близость керамических комплексов аким-сергеевского и атабаевского этапа маклашеевской культуры неоднократно отмечалась исследователями (Ставицкий, 2008, с. 201; Чижевский и др., 2019 , с. 100). Подобная гибридная керамика с различными орнаментальными чертами отражает процесс взаимодействия культур леса и степи в рамках третьего периода развития Западноазиатской (Евразийской) металлургической провинции (Кузьминых, Дегтярева, 2006, c. 251-254).

На более поздней атабаевской керамике отмечается тенденция к исчезновению орнаментальных зон ниже ямочных или каплевидных вдавлений на шейке сосуда. Валик уплощается и становится схож с маклашеевскими воротничками финала бронзы (рис. 11: 1-5, 7, 8).

Таким образом, на территории стоянки мы имеем дело с наиболее ранним взаимодействием носителей КТК и раннемаклашеевской (атабаевской) культур. Судя по находкам ранних текстильных комплексов на дне сооружения 1 и залеганию ранней атабаевской и текстильной керамики в хозяйственных ямах, время постройки сооружения можно определить в пределах XIV в. до н. э. (или даже рубежом XV-XIV вв. до н. э.), учитывая известные даты валиковых и текстильных комплексов (Колев, 2008, с. 225; Лавенто, Патрушев, 2015; Чижевский и др., 2019, с. 108).

Самыми поздними по времени (XII-X вв. до н. э.) могут считаться не столь многочисленные находки (82 фрагмента, или $11 \%$ от всей определенной керамики) фрагментов керамики маклашеевской культуры и КТК финала позднего бронзового века. Эта 


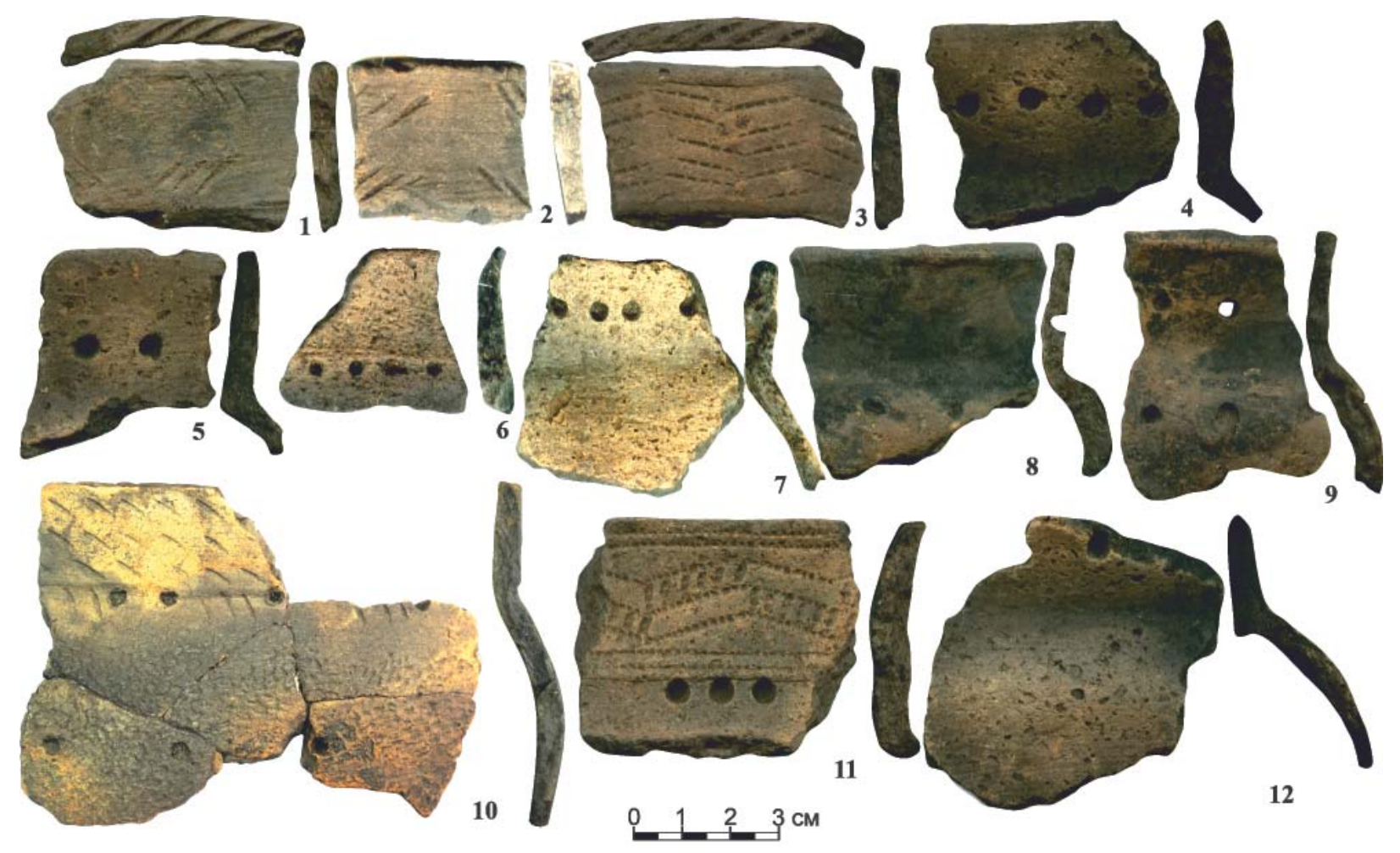

Рис. 12. Керамика маклашеевского этапа маклашеевской культуры и культуры текстильной керамики гибридного облика, залегающая в верхней части заполнения землянок 1-2.

Fig. 12. Ceramics of the Maklasheevka stage of the Maklasheevka culture and the textile ceramics culture of hybrid appearance, lying in the upper part of the filling material of dugouts 1-2.

керамика представлена как классической маклашеевской с примесью в тесте раковины со сгруппированными ямками, идущими ниже воротничка (рис. 12: 11), так и гибридной керамикой с примесью песка в тесте, с текстильными отпечатками по тулову сосуда, с ямками, идущими по венчику и по тулову сосудов (рис. 12: 1-5, 8-10, 12). Симбио3 гончарных традиций отражает процесс дальнейшего смешения носителей культур текстильной керамики и маклашеевской. В основном маклашеевская и текстильная керамика финала бронзы залегает в верхней части заполнения котлована землянки (табл. 1). Ее не зафиксировано в нижней части землянки и в материковых сооружениях. Судя по стратиграфическим наблюдениям, носители маклашеевской культуры продолжали использовать котлован жилища более раннего периода. Хорошо сохранившиеся бревна дуба, лежащие в переходе между землянками, относятся к этому времени (рис. 4: 2, 3; 5). К этому же периоду относятся находки большого количества прокаленного колотого кварцита, расположенные в верхней части заполнения землянки 1 (рис. 4: 4). Выраженные кварцитовые орудия, однако, зафиксированы не были.

Получена AMS ${ }^{14} \mathrm{C}$ дата из обугленного бревна дуба, лежащего в переходе между землянками (рис. 4). Некалиброванные значе- ния $2966 \pm 29{ }^{14} \mathrm{C}$ л. н. Калиброванные значения 1 б (68\%) 1224-1125; 2 б (96\%) 1274-1055 кал. л. до н. э. (UOC-13395, INTCAL20). Это время соответствует проживанию на территории стоянки носителей маклашеевской культуры. В дальнейшем, судя по отсутствию находок раннего железного века, жизнь на поселении прекращается. Вероятно, наблюдаемое пожарище в виде обугленных бревен, в непотревоженном виде и в хорошей сохранности, маркирует процесс, когда люди покидают это место.

Помимо керамических сосудов на стоянке были выявлены обломки от двух глиняных напряслиц (рис. 13: 17, 19). Одно из напряслиц орнаментировано ногтевыми вдавлениями, второе - небрежно сделано и неорнаментировано. Аналогии таким напряслицам прослеживаются в поздняковской культуре, атабаевском этапе маклашеевской культуры (Бадер, Попова, 1987, рис. 70; Халиков, 1980, табл. 31).

Кремневый материал стоянки также находит аналогии в культурах энеолита позднего бронзового века. К энеолиту можно отнести разнообразные отходы из одноцветного слоистого серого, реже двухцветного черно-белого кремня хорошего качества, который является маркером энеолита (Лыганов и др., 2018, с. 250-251) (рис. 13: 11). К 


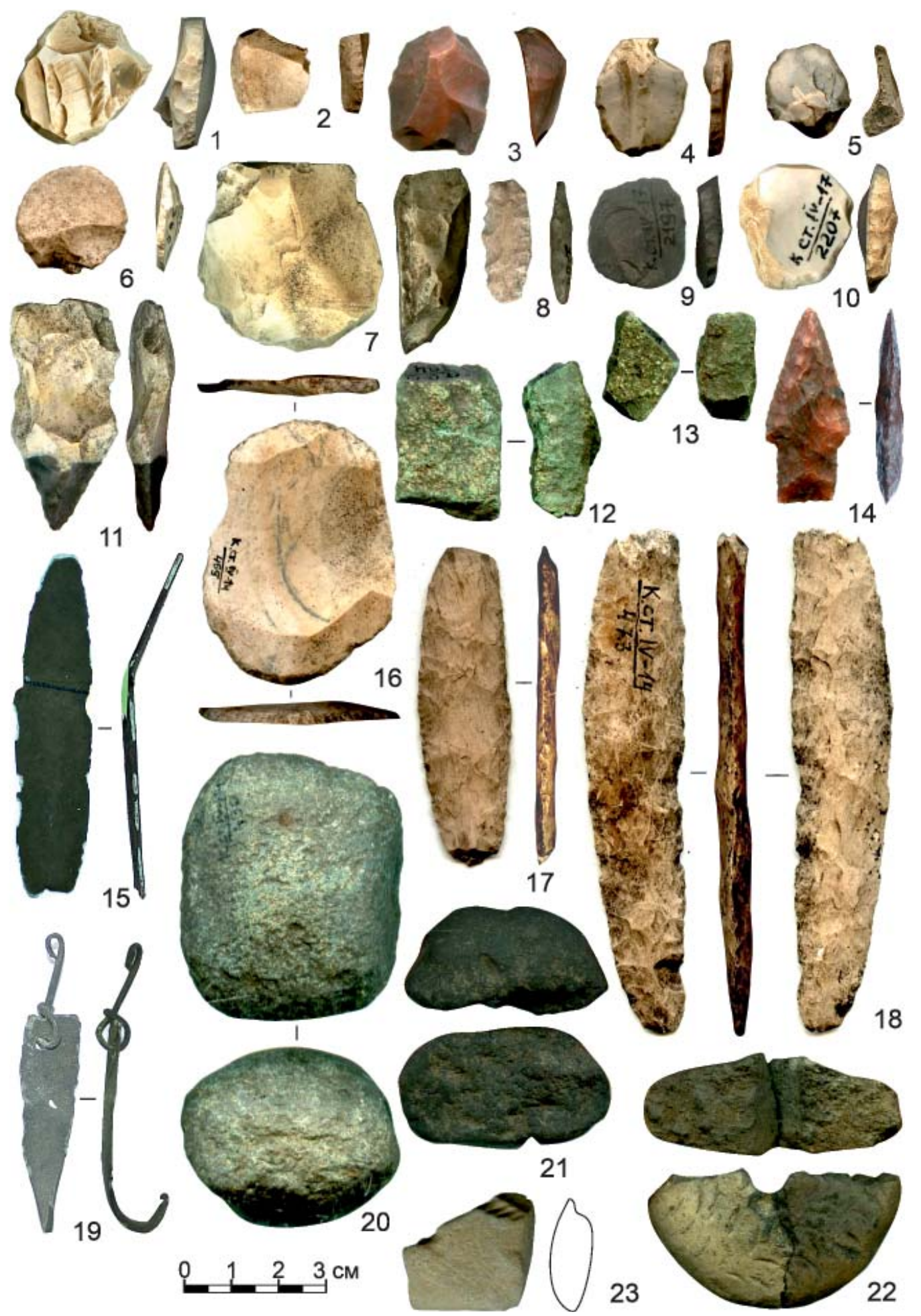

Рис. 13. 1-7, 9, 10 - кремневые скребки с лезвием по периметру, 8, 14 - Кремневые наконечники стрел. 11 - кремневое сверло-долотце. 12, 13 - куски медистого песчанника, 15 - медный нож, 16 - скребок на отщепе с двумя лезвиями, 17-18 - ножи-бифасы, 19 - медный рыболовный крючок, 20 - каменный отбойник, 21-22 - глиняные напряслица, 23 - фрагмент каменной литейной формы?

Fig. 13. 1-7, 9, 10 - Flint scrapers with a perimeter blade, 8, 14 - Flint arrowheads. 11 - flint drill bit. 12, 13 - pieces of cuprous sandstone, 15 - copper knife, 16 - scraper on a flake with two blades, 17-18 - biface knives, 19 - copper fish hook, 20 - hammer stone, 21-22 - clay spinning wheel cover, 23 - fragment of a stone casting mold?

энеолиту также следует отнести и небольшой кремневый наконечник стрелы листовидной формы. Аналогии таким наконечникам прослеживаются в древностях средневолжского варианта волосовской КИО (Никитин, 2017, 317: 2; 340, 351: 4).
Одной из наиболее ярких находок может считаться кремневый наконечник стрелы с вытянуто-треугольным пером и широким черешком подпрямоугольной формы (рис. 13: 14). Подобные наконечники стрел характерны для ряда культур первой фазы позднего 
бронзового века - прежде всего, некрополей сейминско-турбинского транскультурного феномена с влиянием в культуре покровских обычаев металлообработки. Это, в первую очередь, могильники Решное и Юринский (Усть-Ветлужский) (Черных, Кузьминых, 1989, рис. 104: 8-11; Шалахов, 2014, рис. 1: 10-11). Вероятно, данный наконечник стрелы можно связать с носителями культуры с керамикой, изготовленной в «срубных» традициях. Как было отмечено выше, на данной керамике прослеживаются покровские гончарные нормы (баночная форма сосудов, расчесы, разнообразные вдавления).

Среди другой категории кремневого инвентаря интересны находки ножей-бифасов (рис. 13: 17, 18). Такие типы орудий присутствуют на поздняковских памятниках (Бадер, Попова, 1987, рис. 67: 23, 24). На стоянке выявлено большое количество своеобразных мелких скребков с ретушью по всему периметру или по нескольким граням (рис. 13: 1-10). Подобные орудия зафиксированы на поселениях поздняковской культуры и КТК (Азаров, 2013, рис. 5: 4-10) атабаевского этапа маклашеевской культуры (Халиков, 1980, табл. 36: 9-16). Хотя известны подобные скребки в Среднем Поволжье уже начиная с эпохи энеолита (Никитин 2017, рис. 340, 402-404; 424, 432, 438).

Металлические изделия. На Курманаковской IV стоянке найдено два металлических изделия - сломанный сработанный ке фиксируется стержневидный предмет с отходящими от него ребрами жесткости на пластинке (?). Точных аналогий таким готовым металлическим изделиям неизвестно.

Таким образом, Курманаковская IV стоянка представляет собой памятник с напластованиями от финала энеолита до финала бронзового века. Первоначальными поселенцами на этой территории были носители культуры средневолжского варианта волосовской КИО. Судя по наличию валиковой керамики, это происходит в самом финале существования культуры. В дальнейшем здесь поселяются носители культуры керамики, изготовленной в т. н. «срубных» традициях. Керамика этого типа впервые выявлена в Предкамье, в Приказанском Поволжье. Пока данный тип керамики вызывает больше вопросов, чем ответов. Непонятно, как происходило проникновение срубных культурных традиций в Предкамье. Срезы венчиков, отсутствие гребенчатых отпечатков, нехарактерное для срубной керамики, заставляют задуматься о еще какомто компоненте в происхождении данных комплексов. Вероятно, это симбиоз срубных и позднеэнеолитических традиций населения, которое проживало в первой четверти II тыс. до н. э. на этой территории.

Далее здесь проживало население, оставившее керамику, украшенную веревочными отпечатками и вдавлениями. Данный комплекс можно связать с поздняковской

Таблища. 2.

Химический состав медных предметов по результатам спектрального анализа

Table. 2.

Chemical composition of copper items based on spectral analysis results

\begin{tabular}{|c|c|c|c|c|c|c|c|c|c|c|c|}
\hline сн.946 & & $\mathbf{A g}$ & $\mathrm{As}$ & $\mathbf{C u}$ & $\mathrm{Fe}$ & $\mathrm{Mn}$ & $\mathbf{P}$ & $\mathrm{Sn}$ & $\mathbf{S b}$ & $\mathrm{Zn}$ & \\
\hline $\mathbf{1}$ & нож & $\mathbf{0 , 0 9 7}$ & $\mathbf{0 , 0 1 6}$ & $\mathbf{9 9 , 7 7}$ & $\mathbf{0 , 0 0 1 2}$ & $\mathbf{0 , 0 1 4}$ & $\mathbf{0 , 0 5}$ & $\mathbf{0 , 0 0 7 6}$ & $\mathbf{0 , 0 0 1 9}$ & $\mathbf{0 , 0 0 3}$ & $\mathbf{C u}$ \\
\hline $\mathbf{2}$ & $\begin{array}{c}\text { рыболов. } \\
\text { крючок }\end{array}$ & $\mathbf{0 , 0 2 4}$ & $\mathbf{0 , 0 8 8}$ & $\mathbf{9 9 , 0 9}$ & $\mathbf{0 , 7 3}$ & $\mathbf{0 , 0 0 5}$ & $\mathbf{0 , 0 4}$ & $\mathbf{0 , 0 0 0 6}$ & $\mathbf{0 , 0 0 2 3}$ & $\mathbf{0 , 0 0 4}$ & $\mathbf{C u}(\mathbf{F e})$ \\
\hline
\end{tabular}

Определение соотношений химических элементов проведено к. ф-м. н. Храмченковой Р.Х.

нож и рыболовный крючок с блесной (рис. 13: 15, 19), находящие прямые аналогии в древностях маклашеевской культуры (XIVХ вв. до н. э.). (Халиков, 1980, табл. 48, 53; Чижевский и др., 2019, рис. 12). Результаты проведенного спектрального анализа выявили, что это чистая медь, вероятно, добытая из приуральских медистых песчаников (табл. 2).

Помимо готовых металлических изделий на стоянке выявлены куски медистого песчаника и, вероятно, обломок от каменной литейной формы (рис. 13: 12, 13, 23). На облом- культурой. По находкам поздняковской керамики в могильниках совместно с керамикой луговской культуры датировать такие находки на Курманаковской IV стоянке можно в пределах XVII-XV вв. до н. э.

Дальнейшая история Курманаковской IV стоянки связана с маклашеевской культурой и КТК позднего бронзового века. В самом начале взаимодействия этих культур был вырыт котлован землянки, и жилище просуществовало здесь до финала бронзового века. На материалах Курманаковской IV стоянки 
было прослежено, как менялись культурные традиции маклашеевской культуры и КТК. На раннем атабаевском этапе маклашеевской культуры керамика этих двух культурных традиций изготавливалась по собственным канонам, смеси гончарных норм не проис- ходило. В финале позднего бронзового века сосуществование носителей КТК и маклашеевской культуры на стоянке продолжается. При этом отмечено появление гибридной керамики с разнообразным смешением традиций гончарства двух культур.

\section{ЛИТЕРАТУРА}

Азаров E.C. Поселение и грунтовый могильник эпохи бронзы Кораблино // КСИА. 2013. Вып. 230. C. $182-195$.

Археологическая карта Татарской АССР. Предкамье / Отв. ред. А.Х. Халиков. М.: Наука, 1981. 211 с. Бадер О.Н., Попова Т.Б. Поздняковская культура // Эпоха бронзы лесной полосы СССР / Археология СССР / Отв. ред. О.Н. Бадер, Д.А. Крайнов, М.Ф. Косарев. М.: Наука, 1987. С. 131-135.

Галимова М.Ш. Кремневый и кварцитовый инвентарь населения Волго-Камья в предананьинское и ананьинское время // Ананьинский мир: истоки, развитие, связи, исторические судьбы / Археология Евразийских степей. Вып. 20 / Отв. ред. С.В. Кузьминых, А.А. Чижевский. Казань: Отечество, 2014. C. $187-191$.

Галимова М.Ш. Лыганов А.В. Глава 1. Пестречинская IV и II стоянки на р. Меша: стратиграфия, планиграфия, результаты раскопок // Пестречинские стоянки эпохи раннего металла и раннего железа в Нижнем Прикамье и их природное окружение / Археология Евразийских степей. 2019. №4. С. 35-91.

Збруева A.B. Памятники эпохи поздней бронзы в Приказанском Поволжье и Нижнем Прикамье // Труды Куйбышевской археологической экспедиции. Т. ІІІ. / МИА. № 80. / Отв. ред. А.П. Смирнов. М.: AH CCCP, 1960. C. 10-95.

Калинин Н.Ф., Халиков А.Х. Итоги археологических работ за 1945-1952 гг. // Труды Казанского филиала Академии наук СССР. Серия исторических наук. Казань: Таткнигоиздат, 1954. 126 с.

Колев Ю.И. Ивановская культура позднего бронзового века: характеристика культуры и проблемы исследования // Актуальные проблемы археологии Урала и Поволжья / Отв. ред. Д.А. Сташенков. Самара: СОИКМ, СамГУ, 2008. С. 208-240.

Кузьлина О.В. І Шигонское поселение // Вопросы археологии Поволжья. Вып. 6 / Отв. ред. М.А Турецкий. Самара: Книжное Издательство, 2017. С. 279-390.

Кузьминых С.В., Дегтярева А.Д. Поздний бронзовый век // Археология: Учебник / Под ред. В.Л. Янина. М.: МГУ, 2006. С. 219-270.

Лавенто M.T., Патрушев В.C. Развитие и хронология текстильной керамики в Среднем и Верхнем Поволжье: критический взгляд на условно принятые ${ }^{14} \mathrm{C}$-даты, АМС-датирование и типологическую хронологию // Поволжская археология. 2015. №2 (12). С. 160-188.

Лыганов А.В. Археологические исследования Курманаковской IV стоянки // АО 2017 года / Отв. ред. Н. В. Лопатин. М.: ИА РАН, 2019а. С. 339-340.

Лыганов A.B. Курманаковская IV стоянка финала энеолита и позднего бронзового века в нижнем течении реки Меша (предварительные результаты исследований) // Поволжская археология. 2019б. №3 (29). C. 34-50. DOI: 10.24852/pa2019.3.29.34.50

Льганов А.В., Хамзин Р.Н., Галимова М.Ш. Материалы эпохи раннего металла Исаковского городища на реке Свияга // Поволжская археология. 2018. №3. С. 242-257.

Малов Н.M. Хронология и периодизация позднего бронзового века Нижнего Поволжья: хвалынская культура валиковой керамики // Проблемы периодизации и хронологии в археологии раннего металла Восточной Европы: Материалы тематической научной конференции / Отв. ред. Е.А. Черленок. СПб.: Скифия-принт, 2013. С. 102-117.

Никитин B.B. На грани эпохи камня и металла. Средневолжский вариант волосовской культурно-исторической общности / Материалы и исследования по археологии Поволжья и Урала. Вып. 10. Йошкар-Ола: МарГУ, 2017. 765 с.

Никитин А.Л. Могильник Дикариха на Плещеевом озере (раскопки 1961 и 1964 гг.) // СА. 1973. №2. C. $158-177$.

Патрушев В.C. «Текстильная» керамика Марийского Поволжья (по материалам раскопок поселений эпохи бронзы) // Поволжская археология. 2017. №1(19). С. 92-113.

Соловьев Б.С. Бронзовый век Марийского Поволжья / Труды МАЭ. Т. VI. Йошкар-Ола: МарНИИ, 2000. $264 \mathrm{c}$.

Ставиикий В.В. Бронзовый век // Археология Мордовского края: Каменный век, эпоха бронзы / ред. В.В. Ставицкий, В.Н. Шитов. Саранск: МордНИИ, 2008. С. 134-209.

Халиков А.X. Материалы к изучению истории населения Среднего Поволжья и Нижнего Прикамья в эпоху неолита и бронзы / Труды МАЭ. Т. І. Йошкар-Ола: Мар. кн. изд-во, 1960. 264 с.

Халиков А.Х. Приказанская культура / САИ. Вып. В1-24. М.: Наука, 1980. 129 с. 
Черных E.H. Кузьлиных С.В. Древняя металлургия Северной Евразии (сейминско-турбинский феномен). М: Наука, 1989. 320 с.

Чижевский А.А., Губин А.С., Льганов А.В. Коминтерновский курган № 2 // Урало-Поволжье в древности и средневековье. Материалы международной научной конференции V Халиковские чтения / Археология Евразийских степей. Вып. 11 / Отв. ред. Ф.Ш. Хузин. Казань: Институт истории АН РТ, 2011. C. 261-271.

Чиюсевский А.А., Лыганов А.В., Кузьминых С.В. Ранний (атабаевский) этап маклашеевской культуры // Археология Евразийских степей. 2019. №2. С. 99-123.

Шалахов Е.Г. Кремневый комплекс Усть-Ветлужского могильника сейминско-турбинского типа // Сохранение и изучение культурного наследия Алтайского края. Вып. ХХ. / Отв. ред. А.А. Тишкин, В.П. Семибратов. Барнаул: Алт. ун-т, 2014. С. 194-198.

Шипилов А.В. Энеолит Икско-Бельского междуречья (по материалам поселенческих памятников). Казань, 2021. 358 с. (в печати).

\section{Информация об авторе:}

Лыганов Антон Васильевич, кандидат исторических наук, старший научный сотрудник, Институт археологии им. А.Х. Халикова АН РТ (г. Казань, Россия): liganov.anton@yandex.ru

\section{REFERENCES}

Azarov, E. S. 2013. In Kratkie soobshcheniia Instituta arkheologii (Brief Communications of the Institute of Archaeology) 230. 182-195 (in Russian).

Khalikov, A. Kh (ed.). 1981. Arkheologicheskaia karta Tatarskoi ASSR. Predkam'e (Archaeological Map of the Tatar ASSR. Cis-Kama River area). Moscow: "Nauka" Publ. (in Russian).

Bader, O. N., Popova, T. B. 1987. In Bader, O. N., Krainov, D. A., Kosarev, M. F. (eds.). Epokha bronzy lesnoi polosy SSSR (The Bronze Age in the Forest Zone of the USSR). Series: Archaeology of the USSR 8. Moscow: "Nauka" Publ., 131-135 (in Russian).

Galimova, M. Sh. 2014. In Kuzminykh, S. V., Chizhevsky, A. A. (eds.). Anan'inskii mir: istoki, razvitie, sviazi, istoricheskie sud'by (The World of Ananyino: Origins, Evolution, Relations, Historical Fate). Series: Arkheologiia Evraziiskikh stepei (Archaeology of Eurasian Steppes) 20. Kazan: "Otechestvo" Publ., 187-191 (in Russian).

Galimova, M. Sh., Lyganov, A. V. 2019. In Arkheologiia Evraziiskikh stepei (Archaeology of Eurasian Steppes) 4, 35-91. (in Russian).

Zbrueva, A. V. 1960. In Materialy i issledovaniia po arkheologii (Materials and Studies in the Archaeology) 80. Moscow: "Nauka" Publ., 10-95 (in Russian).

Kalinin, N. F., Khalikov, A. Kh. 1954. Trudy Kazanskogo filiala Akademii nauk SSSR. Seriia istoricheskikh nauk (Proceedings of the Kazan Branch of the USSR Academy of Sciences. Historical Sciences Series). Kazan: "Tatknigoizdat" Publ. (in Russian).

Kolev, Yu. I. 2008. In Stashenkov, D. A. (ed.). Aktual'nye problemy arkheologii Urala i Povolzh'ia (Topical Issues in the Urals and Volga Regions Arcaheology). Samara: Samara Regional Museum of Local Lore named after P. V. Alabin, Samara State University, 208-240 (in Russian).

Kuz'mina, O. V. 2017. In Turetskii, M. A. (ed.). Voprosy arkheologii Povolzh'ia (Issues of Archaeology of the Volga Region) 6. Samara: "Knizhnoe Izdatel'stvo" Publ., 279-390 (in Russian).

Kuz'minykh, S. V., Degtiareva, A. D. 2006. In Yanin, V. L. (ed.). Arkheologiia: uchebnik (Archaeology: a tutorial). Moscow: Moscow State University Publ., 219-270 (in Russian).

Lavento, M. T., Patrushev, V. S. 2015. In Povolzhskaya arkheologiya (Volga River Region Archaeology) 12 (2), 160-188 (in Russian).

Lyganov, A. V., Khamzin, R. N., Galimova, M. Sh. 2018. In Povolzhskaya arkheologiya (Volga River Region Archaeology) 25 (3), 242-257 (in Russian).

Lyganov, A. V. 2019a. In Lopatin, V. N. (ed.). Arkheologicheskie otkrytiia 2017 (Archaeological Discoveries of 2017). Moscow: Institute of Archaeology, Russian Academy of Sciences, 339-340 (in Russian).

Lyganov, A. V. 2019b. In Povolzhskaya arkheologiya (Volga River Region Archaeology) 29 (3), 34-50. DOI: 10.24852/pa2019.3.29.34.50 (in Russian).

Malov, N. M. 2013. In Cherlenok, E. A. (ed.). Problemy periodizatsii i khronologii v arkheologii epokhi rannego metalla Vostochnoy Evropy: Materialy tematicheskoy nauchnoy konferentsii (Issues of Periodization and Chronology in the Archaeology of the Early Metal Period of Eastern Europe: Proceedings of the Thematic Scientific Conference). Saint Petersburg: "Skifiya-print" Publ., 102-117 (in Russian).

Nikitin, V. V. 2017. Na grani epokhi kamnya i metalla. Srednevolzhskiy variant volosovskoy kul'turnoistoricheskoy obshhnosti (Between the Stone and Metal Periods. Middle Volga Variation of the Volosovo Cultural and Historical Community). Series: Arkheologiia Povolzhia i Urala. Materialy i issledovaniia (Volga and the Urals Archaeology. Materials and Studies) 10. Yoshkar-Ola: Mari State University (in Russian).

Nikitin, A. L. 1973. In Sovetskaya arkheologiya (Soviet archeology). (2). 158-177 (in Russian). 
Patrushev, V. S. 2017. In Povolzhskaya arkheologiya (Volga River Region Archaeology) 19 (1), 92-113 (in Russian).

Solov'ev, B. S. 2000. Bronzovyi vek Mariiskogo Povolzh'ia (Bronze Age of Mari Volga Area). Series: Proceedings of the Mari Archaeological Expedition VI. Yoshkar-Ola: Mari Research Institute of Language, Literature, and History (in Russian).

Stavitskii, V. V. 2008. In Stavitskii, V. V., Shitov, V. N. (eds.). Arkheologiia Mordovskogo kraia: Kamennyi vek, epokha bronzy (Archaeology of the Mordva Land: Stone Age and Bronze Period). Saransk: Research Institute of the Humanities by the Government of the Republic of Mordovia, 134-209 (in Russian).

Khalikov, A. Kh. 1960. Materialy k izucheniiu istorii naseleniia Srednego Povolzh 'ia i Nizhnego Prikam 'ia $v$ epokhu neolita i bronzy (Materials for the Study of the History of Population of the Middle Volga and Lower Kama Regions in the Neolithic and Bronze Age). Series: Trudy Mariiskoi arkheologicheskoi ekspeditsii (Proceedings of Mari Archaeological Expedition) I. Yoshkar-Ola: "Mariiskoe knizhnoe izdatel'stvo" Publ. (in Russian).

Khalikov, A. Kh. 1980. Prikazanskaia kul'tura (The Prikazanskaya Culture). Series: Svod Arkheologicheskikh Istochnikov (Corpus of Archaeological Sources) 1-24. Moscow: "Nauka" Publ. (in Russian).

Chernykh, E. N., Kuzminykh, S. V. 1989. Drevniaia metallurgiia Severnoi Evrazii (seiminsko-turbinskii fenomen) (Ancient Metallurgy of Northern Eurasia (Seyma-Turbino Phenomenon)). Moscow: "Nauka" Publ. (in Russian).

Chizhevsky, A. A., Gubin, A. S., Lyganov, A. V. 2011. In Khuzin, F. Sh. (ed.). Uralo-Povolzh'e v drevnosti $i$ srednevekov'e. V Khalikovskie chteniia (Ural and Volga Area in Antiquity and Middle Ages: $5^{\text {th }}$ Khalikov Readings). Series: Arkheologiia Evraziiskikh stepei (Archaeology of Eurasian Steppes) 11. Kazan: Institute of History, Tatarstan Academy of Sciences, 224-230 (in Russian).

Chizhevsky, A. A., Lyganov, A. V., Kuzminykh, S. V. 2019. In Arkheologiia Evraziiskikh stepei (Archaeology of Eurasian Steppes) 2, 99-123 (in Russian).

Shalakhov, E. G. 2014. In Tishkin, A. A., Semibratov, V. P. (eds.). Sokhranenie i izuchenie kul'turnogo naslediia Altaiskogo kraia (Preservation and Study of the Cultural Heritage of Altai Krai) 20. Barnaul: Altai State University Publ., 194-198 (in Russian).

Shipilov, A. V. (in print). Eneolit Iksko-Bel'skogo mezhdurech'ia (po materialam poselencheskikh pamiatnikov) (Eneolithic of the Ik-Belaya Interfluve (Based on Materials from Populated Settlements)). Kazan (in Russian).

Abou the Author:

Lyganov Anton V. Candidate of Historical Sciences. Institute of Archaeology named after A.Kh. Khalikov, Academy of Sciences of the Republic of Tatarstan. Butlerov St., 30, Kazan, 420012, Republic of Tatarstan, Russian Federation; liganov.anton@yandex.ru 